\title{
AZ ALFÖLD ÉS AZ ÚJ EURÓPAI TERÜLETFEJLESZTÉSI PERSPEKTÍVÁK ${ }^{1}$ (The Great Hungarian Plain and the New Perspectives of Regional Development in Europe)
}

\author{
CSATÁRI BÁLINT
}

\begin{abstract}
Bevezetó
Az Alföld hazánk egyik legkarakteresebb nagyrégiója. Környezeti állapota és annak veszélyeztetettsége, gazdaságának strukturális problémái, infrastruktúrájának viszonylagos elmaradottsága, kủlönleges szerkezetủ telepủléshálózata, társadalmának erős identitása mind olyan történeti, földrajzi, társadalmi vagy összefoglaló néven regionális tényezö, amelyről mindig újra és újra értekeznünk szükséges.

Fontos tény, hogy az elmúlt másfél évszázad magyar teruleti fejlődésének értékelésében minden jelentős gazdasági, társadalmi, politikai fordulat után újra fellángolnaik az Alfoold viták. Akár úgy, hogy már megint „,kettészakad az ország”, akár úgy, hogy ,...az Alfóld a magyarság szíve, s ami ott sikertelen, az más részeken erőre kapni, s a hazára nagy befolyást gyakorolni nem fog".2

$\mathrm{S}$ valóban, a reformkorban már találhatók itt feudális korlátoktól részben mentes mezővárosok, melyeknek különlegesen organikus a gazdasági és társadalmi fejlỏdése. Az alföldi tanyarendszerek kialakulása sok esetben jobban hasonlít a frontier típusú, amerikai utas agrárfejlődéshez, mint a poroszhoz. A folyószabályozások nyomán megnövekedő mezőgazdasági élettér gyors elfoglalásával, a monarchia védett piacán az Alföld valóban gyorsan zárkózott fel. Rendkívüli hatása volt a régió szellemiségére Klebelsberg Kuno tudatos, az Alföld nagyvárosait és tanyavilágát megcélzó oktatás- és kultúrpolitikájának is. Az esetenként ma már szinte idealizáltnak feltüntetett, e régióra jellemzó paraszt-polgári fejlődés révén az alfơldi városok nagy többségében erős oktatási intézményrendszer épült ki. Fontos momentumai voltak e fejlödésnek: a magas színvonalú munkakultúra, a szorgalom, az egyes alfơldi tájegységekhez is jellegzetesen kơthetỏ életforma különbségek, az erös és részben egyházi alapon is megszervezett, jól múkődő helyi önkormányzatok, a lokális „mi tudatok” és kibontakozásuk lehetősége. Az „úgynevezett” alföldi mentalitást és identitástudatot, a táj- és földszeretetet a szépirodalom, a költészet vagy éppen a népi írók mozgalma helyezte időnként a kőzérdeklödés és a magyar szellemiség középpontjába.

Mindezek alapján nyilvánvalóan nem véletlen, hogy az 1989/90-es rendszerváltáskor ismét olyan fordulópontot értünk meg, amely a manapság Európában jellemző regionális érdeklődés viszonylagos fókuszába állította az Alföldet. Az alfơldi megyék megalakították a Nagyalfơld Alapítványt, az elsỏ szabadon választott Országgyülés határozatot hozott a régió egységes, az ökológiai és az őkonómiai felté-
\end{abstract}


telekre egyaránt tekintettel levő, sajátos Alföld-fejlesztés szükségességéröl. Kétéves nagyszabású Alföld Kutatási Program folyt le. Az MTA Regionális Kutatások Központján belül újjáalakult az Alföldi Tudományos Intézet. Egy 1994. májusi kormányhatározat nyomán elindult az úgynevezett Alföld Program is, melynek bizonyos részsikerei ugyan voltak, de akkor még - szakszerü területfejlesztési törvény és intézményrendszer hiányában - a sok, fontos határozatba foglalt terv megvalósulása még nem teljesedhetett ki.

A múlt és napjaink Alföld ,ügyeinek" e nagyon vázlatos áttekintése után méltán tehető fel a kérdés: miben rejlik a ma és a közeljövő Alföld problematikája?

A rövid válasz az, hogy változatlanul az Alföld „másságában”, az ország, sőt Közép-Európa más térségeitől való sajátos - szinte differencia specifikákként is definiálható - különbözőségeiben, amelyek egyszerre jelenthetnek a jövő számára előnyt és hátrảnyt. Az Alföld egészében nem elmaradott és/vagy leszakadó régiója az országnak, hanem „másságokkal”, ha úgy tetszik tradíciókkal, képességekkel, fejlett intézményrendszerű városhálózattal, adaptáció- és megújulóképes társadalommal, komparatív mezőgazdasági előnyökkel, igen értékes természeti-környezeti értékekkel rendelkező és a nagy kelet-közép-európai régiók felé nyitott, nagytávlatú együttmüködésre képessé tehető nagytáj. A hat megye 3,5 millió lakosának jövője attól is függ, hogy most is megtalálja azokat a mai kornak megfelelö, modernizációs lépéseket, amelyeket egykoron többször is sikeresen megtalált.

Jelen tanulmányunk ehhez kíván néhány szempontot felvázolni. Arra vállalkozunk, hogy az ún. Európai Területfejlesztési Perspektíva c. dokumentum egyes fỏ fejezeteihez kapcsolódva áttekintjük, hogy milyen lehetöségei és korlátai vannak mintegy európai összevetésben - az Alföldnek.

\section{A területi struktúrák és a kohézió az Alföldön}

Az európai közösségi politikában fokozódó szerep jut az ún. egységes fejlesztéspolitikának. A fő cél, mint megannyiszor deklarálták, a területek kiegyensúlyozott és harmonikus fejlődése, amely nem pusztán az általános területfejlesztést jelenti, hanem mindig az adott területek sajátosságaiból kiindulva, az egyes térségek legfontosabb fejlesztési összetevőinek figyelembevételét. Az ún. ágazatpolitikai (pl. mezőgazdasági-, közlekedés-, vagy környezetpolitikai) célokat is szigorúan a területi hatásaikra tekintettel valósítják meg. A területi kohézió a települések, a mikrotérségek, a megyék, a régiók belső, eredményes partneri viszonyait megteremtő együttmüködése.

Az Alföld egésze - mérete, mássága, érintettsége (pl. az új agrárpolitika vagy az Európát átszelő hálózatok fejlesztése, stb.) okán - mint régió, komoly, potenciális regionális integrációs lehetőségekkel bír. Mint a korábbi Alföld Kutatási Program is igazolta, régiónk legfontosabb fejlesztési összetevői - pl. a szomszédos országokkal összekapcsolódó vízrendszerének környezeti igényei, vagy a jelentôs közlekedésitranzit szerep - egybeesnek ezekkel a nagy, új összeurópai célkitüzésekkel. Az Alföld e téren való alkalmazkodóképességének korlátai, gyengéi közismertek. 
Hiányzik az a modern közúti és vasúti hálózati rendszer, amely ezt a tranzitfejlesztési lehetőséget valóban teljes értékủen kialakíthatóvá tenné. Szükek a kapacitások, kevés a híd, a nagyobb településeket elkerülő út, a növekvő forgalom lebonyolítására alkalmas, jól ellátott határállomás.

Sajnos a települési-társadalmi kohézió is gyenge még. Bár mind a belső térségi együttmúködẻseket illetően, mind a határmenti, sőt az euroregionális kapcsolatok tekintetében is kedvezö jelek tapasztalhatók (Kárpátok Eurorégió, Duna-KörösMaros-Tisza Eurorégió megalakulása), de fontos tény, hogy külső, nemzetközi integrációra és kohézióra csak sikeres, belső, település-, kistérség- és megyeközi kohéziós egylittmükődések nyomán van valódi lehetőség. A területi kohézió alföldi regionális sajátossága lehetne a sokszinü, történeti-táji szervezỏdések újjáteremtése. Ezek egy része, a legkülönbözöbb területeket lefedő szerveződések, kistérségi társulások, szövetségek formájában elkezdtek ugyan megszervezödni, de a területfejlesztési törvény nyomán megalakított hivatalos KSH kistérségek nem tudták „befogadni” ezeket a sokféleségükben egyfajta területi összetartozást, kohéziót kifejező és részben megjelenitő, önszervezőđő̆ alföldi kistérségeket. A valódi területi kohézióra épitő, már az évtized első felében megalakult nagyszámú alföldi kistérségi szervezet-csirák sokkal adekvátabb táji-térségi egységeket alkotva (pl. Felső-Bácska, Dél-Békés) sem tudnak egyelöre továbbfejlődni, aminek a másik oka, hogy a területfejlesztés e szintjére érkező tényleges források mértéke annyira elmarad a valódi és reális igényektől, hogy szinte kilátástalanná teszi a szereplök számára a szoros szervezeti-fejlesztési egyltttmúködés lehetőségét, s néha annak az értelmét is.

A kohéziónak minden fentebb sorolt szinten más-más a tartalma. A szereplők e pontosan meghatározott tartalmak, a megfelelö források, illetve a területfejlesztési folyamatok kohézióját biztosító professzionális intézményrendszer hiányában nem tudják megvalósitani - a ma már nagy számban elkészült - kistérség-fejlesztési koncepcióikat és programjaikat sem. Pedig az elmúlt két esztendőben az Alfơld Program keretében meghirdetett kormányzati (alföldi tanyafejlesztési, ökotérségi) pályázatok iránt igen nagy volt a régió kistérségeinek az érdeklődése. Valódi kohéziót jelzett, de nem a hivatalos KSH kistérségek szintjén, illetve keretei között.

Az egész Alföld nagyrégiójának területi kohéziója - bár mind a hat megyére érvényesíthetö, s így homogén területi problémák létezését, vagyis az „összalföldi” problémák közös kezelésének és részben megoldásának lehetöségét, szükségességét a kutatói szférán kívül is sokan elfogadják és hangoztatják - nemhogy erösödne, inkább gyengül. Ennek egyik oka, hogy az alföldi régiók és megyék az éleződő területi versenynek még mindig szinte kizárólagos vesztesei. Tehát aligha bizzhatnak benne, hogy együtt nyertesek lehetnek.

A másik ok valószínủsíthetően az, hogy a területfejlesztés regionális beosztásának tervezetei között fel sem merült az Alföldnek, mint NUTS I szintủ régiónak a besorolási lehetösége, holott ennek - a korábbi és a jelenlegi Alföld kutatások alapján is - egyértelmü bizonyítékai vannak. Ez nemcsak az egész Nagyalföld területére sok 
tényező alapjản kimutatható homogenitás alapján fogalmazható meg, hanem azoknak az új területfejlesztési perspektíváknak a tekintetében is, amelyek az ország, vagy még inkább a Kárpát medence léptékében az EU csatlakozás után az Alföldre érvényesithetők lennének.

A továbbiakban megkíséreljük sorra venni az új Európai Területfejlesztési Perspektíva címü dokumentum vizsgált régiónkra érvényesíthető főbb elveit, és az azokból kibontható alföldi lehetőségeket.

\section{A közös mezógazdasági politika}

A közös mezőgazdasági politika az ország és az Alföld reménybeli csatlakozásának kétségtelenül az egyik legneuralgikusabb pontja. Az elmúlt évek EU agrárpolitikája elsösorban a nagy termelékenységủ mezőgazdaságnak adott prioritást. Ugyanakkor a túltermelés csökkentése érdekében „1993-94-ben mintegy 6 millió hektár területet vontak ki a termelésből" (Európai Területfejlesztési Perspektiva 1998b, 32). Érdekes folyamat volt az állatállomány csökkentése, amely egyes területeken a földmủvelés helyreállításához vezetett. Összességében a kevésbé intenziven termelö régiók viszorylag kedvezőtlenebb helyzetbe kerültek.

Az Alföld agráriumának vélhetöen mindkét irányban - tehát az intenzív, a komparatív és egyedi, minőségi előnyeinket érvényesíteni képes, illetve az extenziv, tájkímélő irányzatokat tekintve is - meg kell és lehet találnia a lehetöségeket az új perspektíva keretei között. Érdekes tény, de az Alföld történeti fejlödésének felívelö szakaszaiban a mezőgazdaságnak mindig jelentős szerepe volt. Igaz ez a múlt század utolsó évtizedeire, a Monarchia védett piacaira, de érvényes a volt KGST keretei között is. Ha a valóban versenyképes, egyedi minöséget elöállítani képes alföldi élelmiszergazdaság mellett a régió megoldást tud találni új gazdasági ágazatok befogadására, telepítésére, $\mathrm{s}$ a modern, fenntartható vidékfejlesztés keretei között az ön- és tájfenntartó mezőgazdaság, erdőgazdaság támogatására, akkor nemcsak e feltételrendszernek felelnénk meg, hanem az EU ủj környezetpolitikájának is. Hiszen e tekintetben a termelö tevékenységeket szigorú ökológiai szabályok alapján kell az adott környezeti adottságokhoz illeszteni.

Az alföldi mezőgazdasági tájkörzetek között különös súllyal kell megjelenniük az ún. hungaricumokat védett és állandó minőségben elóllító területeknek, tekintettel a zöldség, gyümölcs, szőlö- és bortermelö térségekre vagy a régióban a kívánatosnál és az elfogadhatónál jobban visszaesett állattartási ágazatokra is. Ekkor sem maradhat el azonban a mezőgazdaság dominanciájával jellemezhető alföldi térségek gazdaságának diverzifikálása.

\section{A környezetpolitika}

Az EU e téren érvényes prioritásai (vízvédelem, a nitrátosodás elleni fellépés, az ökológiai hálózatok koncepciója, a fejlesztések környezeti hatásvizsgálatainak elöírásai, LIFE, NATURA 2000 stb. elöírásai) kiemelten érdekében állnak az Alföldnek is. Sőt ezekhez a programcsoportokhoz a nagy értékü Nemzeti Parkok és tájvé- 
delmi körzetek, a folyó menti területek vagy az országhatárokon is átnyúló vízrendszerek révén kiválóan csatlakozni is tudna a régió. Az alföldi regionális fejlődés jövőjének egyik kulcsterülete a szigorú környezet- és tájvédelem alkalmazása. E területek szakmai és tervezési háttere is olyan minőségủ, hogy nemzetközi együttmüködésre, érdemi bekapcsolódásra már jóval a csatlakozás jogi aktusa elött képes lehet. Ahhoz, hogy ez igazán sikeres lehessen, természetesen arra is szilkség van, hogy a régió gazdasága, településeinek társadalma is elismerje, hogy az Alföld ebbéli értékei, és azoknak a jövő és Furópa számára való megörzése, bemutatása elemi fontosságú érdeke. A termelés és a védelem „látszólag” ellenérdekeltek. Az Alföld ökológiai harmóniájának visszaállitása, táji rekonstrukciója azonban olyan eurokonform hosszú távú érdek, amelyre mindenképpen tekintettel kell lenni.

\section{Az Európát átszeló hálózatok}

A közösségi politika e téren kettős célkitüzést követ: valamennyi térség jobb megközelíthetőségének elvét, a társadalmi-környezeti feltételekre is tekintettel a kombinált közlekedési módok támogatását. Ezek az Alföldünkön is igen fontos elemek, de a nagy lehetősége a régiónak nemcsak az ezeken az elveken alapuló megoldảsokban van, hanem a nagy európai transzverzális összeköttetések tényleges megvalósításában. A kiterjeszkedö európai közösségi határok révén Magyarország és az Alföld is nagy távlatban - Románia, Ukrajna integrációja nyomán - Európának a valóságos geográfiai centrumába kerul. Már ma is nagy a verseny abban a kérdésben, hogy a nagy nyugat-kelet irányú folyosók hol haladjanak át, milyen összeköttetési lehetóségek teremthetôk Észak- és Dél-Európa, vagy éppen a Mediterráneum és Ukrajna, illetve Oroszország között. Az EU tag Görögország és a NATO tag Törökország már ma is hatalmas átmenỏ forgalmat bonyolít le az Alföldön keresztül. Hasonlóan érinti a régiót a Duna vonalának komplex fejlesztése, vagy azok az egyre inkább megfogalmazódó román igények, amelyek értelemszerủen az „Alföldön keresztül” kívánják megoldani az európai csatlakozás közúti, vasúti feltételeit. Hatalmas fejlesztési lehetőségek rejlenek az Alfơld városai, határmenti területei számára e lehetỏségek potenciális kihasználásában. A kombinált szállitási formák megteremtésében (debreceni repülótér, tiszai hajózás, logisztikai központok, átrakó, csomagoló, deponáló telepek, vámszabad területek, határokon átnyúló különleges gazdasági vagy vállalkozási övezetek stb.).

Ezen nagy általános, összeurópai fejlesztési elvekhez és programokhoz való kapcsolódásunk alföldi aspektusai tehát eléggé kézenfekvónek látszanak. De a jövő lehetőségei nemcsak ezekből vezethetök le, hanem a nagy regionális politikai célok szerinti egyes nagy alprogramokhoz való csatlakozási lehetőségekból is. A mai Európai Unió belső, regionális politikája is változások előtt áll. Ủgy tủnik, hogy a kőzeljövőben jelentős kutatás-fejlesztési programok indulnak el részben a területi politikákat meghatározó, új „területi mutatók” kiválasztására, illetve a területi tipológiák kutatására. 
Az Alföldre is alkaln.azni kell majd azt a hét kritériumból álló rendszert, amely a földrajzi elhelyezkedés, a gazdasági erő, a társadalmi és térbeli integráció, a terület terhelése, a természeti és kulturális vagyon alapján komplexen határozza majd meg azt, hogy milyen típusú fejlesztések preferálására, támogatására alkalmas az adott régió, s hogy mindezek alapján hogyan, s mennyire alkalmas a terïleti integrációra. Mint a fentebb kifejtettek már jelzik, az Alföld igenis alkalmas lehet erre.

$\mathrm{Az}$ utóbbiak rövid igazolására elég áttekinteni a tervezett EU területi politika új irányai közül legalább kettőt.

\section{A kiegyensúlyozottabb, policentrikus városrendszer és egy új urbánus -rurális viszony kialakitása}

Ennek az új európai területfejlesztési elvnek a lehetséges alföldi alkalmazhatóságához és a régió ,másságának” a bizonyításához felhasználtuk az ország és a régió teljes településállományára elvégzett, 25 mutatót tartalmazó sokoldalú faktoranalízist (Beluszky-Csatári 1998, 60).

A teljes településállományra elvégzett analízis vizsgálatba vont mutatórendszerén (népességszám és változása, korösszetétele, munkanélküliség, vállalkozások élénksége, jövedelemviszonyok, infrastrukturális és intézményi ellátottság mutatói, iskolai végzettség $s t b .{ }^{3}$ ) belül, illetve a mutatók között nagyon kevés szoros korreláció található. Ez a faktoranalízis miatt kedvező tény, de arra is utal, hogy a változásokat jelző mutatók között kevés az 'együtt-mozgás', a tényleges és kézenfekvőnek tủnő egymásra hatás.

A teljes településállományon végzett vizsgálatban nem az ilyen elemzéseknél általában a differenciálódást mutató progresszív elemek, hanem a munkanélküliség, a szociális elmaradottság igen magas negatív meghatározottsága emelkedett ki. Vagyis a teljes országos településállományon belül a differenciảlódás elsősorban „lefelé”, negatív irányban erös. Az Alföld ebben az országos összevetésben szinte homogén, elmaradott terület (1. táblázat, 1. ábra). Az igazán kedvezö helyzetú települések száma és népességaránya töredéke az országosnak.

\section{TÁBLÁZAT}

Az általános faktoranalizis fö faktoraihoz tartozó települések számának és népességének megoszlása országosan és az Alföldön

(Distribution of the Number and the Population of Settlements Concerned to the

Principal Fuctors of General Factor Analysis in Hungary and in the Great Plain)

\begin{tabular}{|l|r|r|r|r|r|r|r|r|}
\hline \multirow{3}{*}{ Kategória } & \multicolumn{4}{|c|}{ Országos } & \multicolumn{4}{c|}{ Alföld } \\
\cline { 2 - 9 } & Településszám & \multicolumn{1}{|c|}{ Lakónépesség, 1996 } & \multicolumn{1}{c|}{ Településszám } & \multicolumn{1}{c|}{ Lakónépesség, 1996 } \\
\cline { 2 - 9 } & \multicolumn{1}{|c|}{$\mathrm{db}$} & \multicolumn{1}{c|}{$\%$} & \multicolumn{1}{c|}{ fö } & \multicolumn{1}{c|}{$\%$} & \multicolumn{1}{c|}{$\mathrm{db}$} & \multicolumn{1}{c|}{$\%$} & \multicolumn{1}{c|}{ fó } & $\%$ \\
\hline 1 felett & 451 & 14,71 & 1029498 & 12,54 & 14 & 1,82 & 59704 & 1,77 \\
\hline $0-1$ & 1227 & 40,03 & 3926509 & 47,81 & 243 & 31,64 & 1332961 & 39,56 \\
\hline$-1-0$ & 914 & 29,82 & 2803927 & 34,14 & 341 & 44,40 & 1665516 & 49,43 \\
\hline-1 alatt & 473 & 15,43 & 452658 & 5,51 & 170 & 22,14 & 311463 & 9,24 \\
\hline Összesen & 3065 & 100,00 & 8212592 & 100,00 & 768 & 100,00 & 3369644 & 100,00 \\
\hline
\end{tabular}

Forrás: saját számítás. 


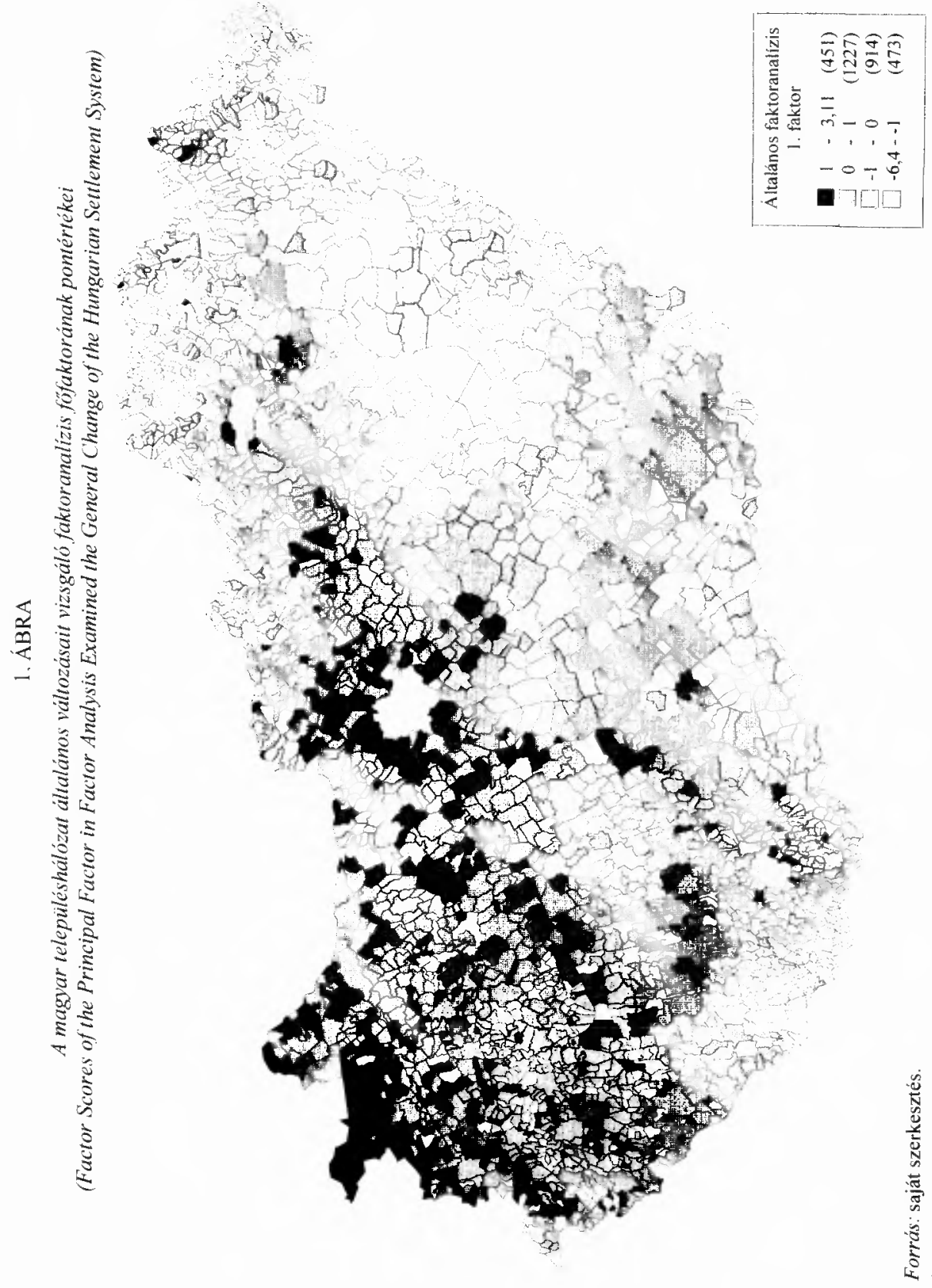


A településméret és az ezzel szoros összefüggést mutató intézményrendszerre utaló mutatók a második faktorba kerültek. Ez részben azt jelzi, hogy a nagyrendszer, tehát a teljes településrendszer belsỏ és az 1. ábrán látható változásai a rendszerváltás óta csak másodlagosan méretfüggők. Ez utalhat arra is, hogy a korábbi településhierarchia változik, átalakul, s a kedvezö települési folyamatok kevésbé alapulnak a megelöző évtizedek ,megszokott” településfejlesztési tényezőire, a nagyságra, az intézményi ellátottságra. Az Alföld régiója e faktor tekintetében hiába van sokkal kedvezóbb helyzerben, úgy tủnik, hogy ezeket az elönyöket még csak részben tudják települései kihasználni (2. táblázat, 2. ábra).

\section{TÁBLÁZAT}

Az általános faktoranalizis 2. faktorához tartozó települések számának és népességének megoszlása országosan és az Alföldön

(Distribution of the Number and the Population of Settlements Concerned to the

2. Factor of General Factor Analysis in Hungary and in the Great Plain)

\begin{tabular}{|c|c|c|c|c|c|c|c|c|}
\hline \multirow{3}{*}{ Kategória } & \multicolumn{4}{|c|}{ Országos } & \multicolumn{4}{|c|}{ Alföld } \\
\hline & \multicolumn{2}{|c|}{ Településszám } & \multicolumn{2}{|c|}{ Lakónépesség, 1996} & \multicolumn{2}{|c|}{ Településszám } & \multicolumn{2}{|c|}{ Lakónépesség, 1996} \\
\hline & $\overline{\mathrm{db}}$ & $\%$ & fó & $\%$ & $\mathrm{db}$ & $\%$ & fó & $\%$ \\
\hline 1 felett & 415 & 13,54 & 5190444 & 63,20 & 179 & 23,31 & 2318373 & 68,80 \\
\hline $0-1$ & 889 & 29,00 & 1772903 & 21,59 & 293 & 38,15 & 724808 & 21,51 \\
\hline$-1-0$ & 1441 & 47,01 & 1126036 & 13,71 & 263 & 34,24 & 303401 & 9,00 \\
\hline-1 alatt & 320 & 10,44 & 123209 & 1,50 & 33 & 4,30 & 23062 & 0,68 \\
\hline Összesen & 3065 & 100,00 & 8212592 & 100,00 & 768 & 100,00 & 3369644 & 100,00 \\
\hline
\end{tabular}

Forrás: saját számitás.

Igazolja ezt az is, ha pontosan ugyanazokkal a mutatókkal, de csak az Alföld településeire végezzük el a hasonló módszerü analízist. Akkor az országos összevetésben „általánosan” elmaradott vizsgált régiónkban egészen más tényezök határozzák meg a változásokat. A differenciálódás az országosan kimutatható tényezőkkel szemben nem „lefelé”, hanem „felfelé" erős. Az alfơldi általános településátalakulást reprezentáló föfaktor tartalmában az új gazdasági szervezetek és az egyéni vállalkozások száma, sürüsége, a magas gépkocsi ellátottság, tehát viszonylag kedvező tényezók jelennek meg. A fentebbi számítással bemutatott, országos tekintetben viszonylag homogénnek tünó alföldi telepủléshálózat magán a régión ,belül" tehát igen differenciáltan fejlödik. Sokkal differenciáltabban, mint azt az országos tendenciáknál tapasztaltuk. A mai fejlödés fỏ tényezói között ugyan itt sem a méret, hanem sokkal inkább a földrajzi helyzet jelenik meg, az országos általános vizsgálattal szemben. Az itt megjelenő „kifejezetten progresszív” mutatók hatása a fófaktorban az alföldi „másság” újabb bizonyítéka lehet. Ezek a kedvezó jelenségek azonban szinte csak a Dél-Alföldön érhetők tetten, míg az Észak-Alföldön csak a városok és közvetlen vonzáskörzeteik néhány települése esett a kedvezö kategóriába (3. ábra, 3. táblázat). 


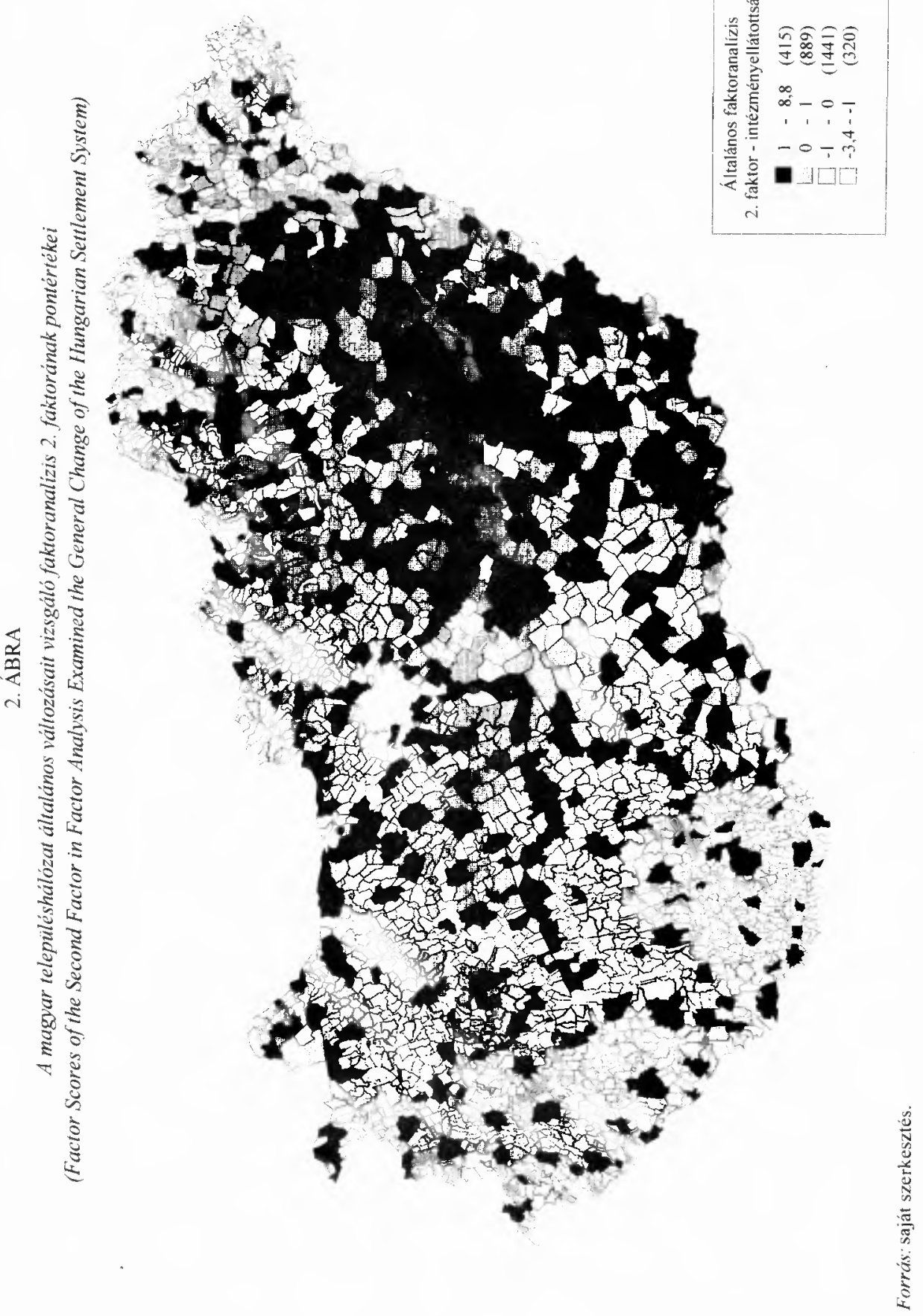





\section{TÁBLÁZAT}

Az alföldi települések általános faktoranalizisének fö faktoraihoz tartozó települések számának és népességének megoszlása (Distribution of the Number and the Population of Settlements Concerned to the Principal Factors of General Factor Analysis in the Great Plain)

\begin{tabular}{|l|c|c|c|c|}
\hline \multirow{2}{*}{ Kategória } & \multicolumn{2}{|c|}{ Településszám } & \multicolumn{2}{c|}{ Lakónépesség, 1996 } \\
\cline { 2 - 5 } & $\mathrm{db}$ & $\%$ & fó & $\%$ \\
\hline 1 felett & 120 & 15,63 & 1447664 & 42,96 \\
\hline $0-1$ & 195 & 25,39 & 794018 & 23,56 \\
\hline$-1-0$ & 367 & 47,79 & 976078 & 28,97 \\
\hline-1 alatt & 86 & 11,20 & 151884 & 4,51 \\
\hline Összesen & 768 & 100,00 & 3369644 & 100,00 \\
\hline
\end{tabular}

Forrás: saját számítás.

A falusi telepủlésekre elvégzett általános analízis legreprezentánsabb negyedik faktora pontértékeinek térbeli képe részben hasonló az általános telepulésvizsgálat fơfaktorához (4. táblázat, 4. ábra). Egyrészt a változásokat reprezentáló faktorok tartalma itt sem utal méretfüggőségre. Másrészt a falusi átalakulás minősége úgy tünik, igen erősen befolyásolt attól, hogy milyen minőségủ és fejlödési dinamikájú városi központhoz tartoznak a falvak. Bár általában még mindig igen fontos ennél a telepủléscsoportnál az infrastruktúra, a telefon vagy a gépkocsi-ellátottság hatása, de az igazi differenciálódást az egyéni és társas vállalkozások száma és aránya „okozza" e faktor értékei szerint. Az Alföld falvai e téren egyértelmúen igen kedvezötlen változásokat mutatnak, s messze elmaradnak más régióktól. Ennek magyarázata lehet az is, hogy a mezőgazdasági tevékenységre utaló mutatók szinte semmilyen összefüggést, változást nem indukáltak a faktorrendszerben, s e tradicionális falusi gazdasági tevékenység alföldi falusi dominanciảja egyértelmủen kedvezőtlen irányba hat az Alfóldo̊n.

\section{TÁBLÁZAT}

A falvak általános faktoranalizisének 4. faktorához tartozó települések számának és népességének megoszlása országosan és az Alföldön

(Distribution of the Number and the Population of Settlements Concerned to the 4. Factor of General Factor Analysis in Hungary and in the Great Plain)

\begin{tabular}{|l|c|c|c|c|c|c|c|c|}
\hline \multirow{2}{*}{ Kategória } & \multicolumn{4}{|c|}{ Országos } & \multicolumn{4}{c|}{ Alfóld } \\
\cline { 2 - 9 } & Telepủlésszám & \multicolumn{2}{|c|}{ Lakónépesség, 1996 } & \multicolumn{3}{c|}{ Településszám } & \multicolumn{2}{c|}{ Lakónépesség, 1996 } \\
\cline { 2 - 9 } & $\mathrm{db}$ & $\%$ & fó & $\%$ & $\mathrm{db}$ & $\%$ & fó & $\%$ \\
\hline 1 felett & 385 & 13,42 & 669388 & 17,97 & 12 & 1,78 & 27880 & 2,04 \\
\hline $0-1$ & 1203 & 41,95 & 1651902 & 44,35 & 204 & 30,22 & 468184 & 34,33 \\
\hline$-1-0$ & 873 & 30,44 & 1085055 & 29,13 & 327 & 48,44 & 668151 & 48,99 \\
\hline-1 alatt & 407 & 14,19 & 317983 & 8,54 & 132 & 19,56 & 199685 & 14,64 \\
\hline Összesen & 2868 & 100,00 & 3724328 & 100,00 & 675 & 100,00 & 1363900 & 100,00 \\
\hline
\end{tabular}

Forrás: saját számítás. 


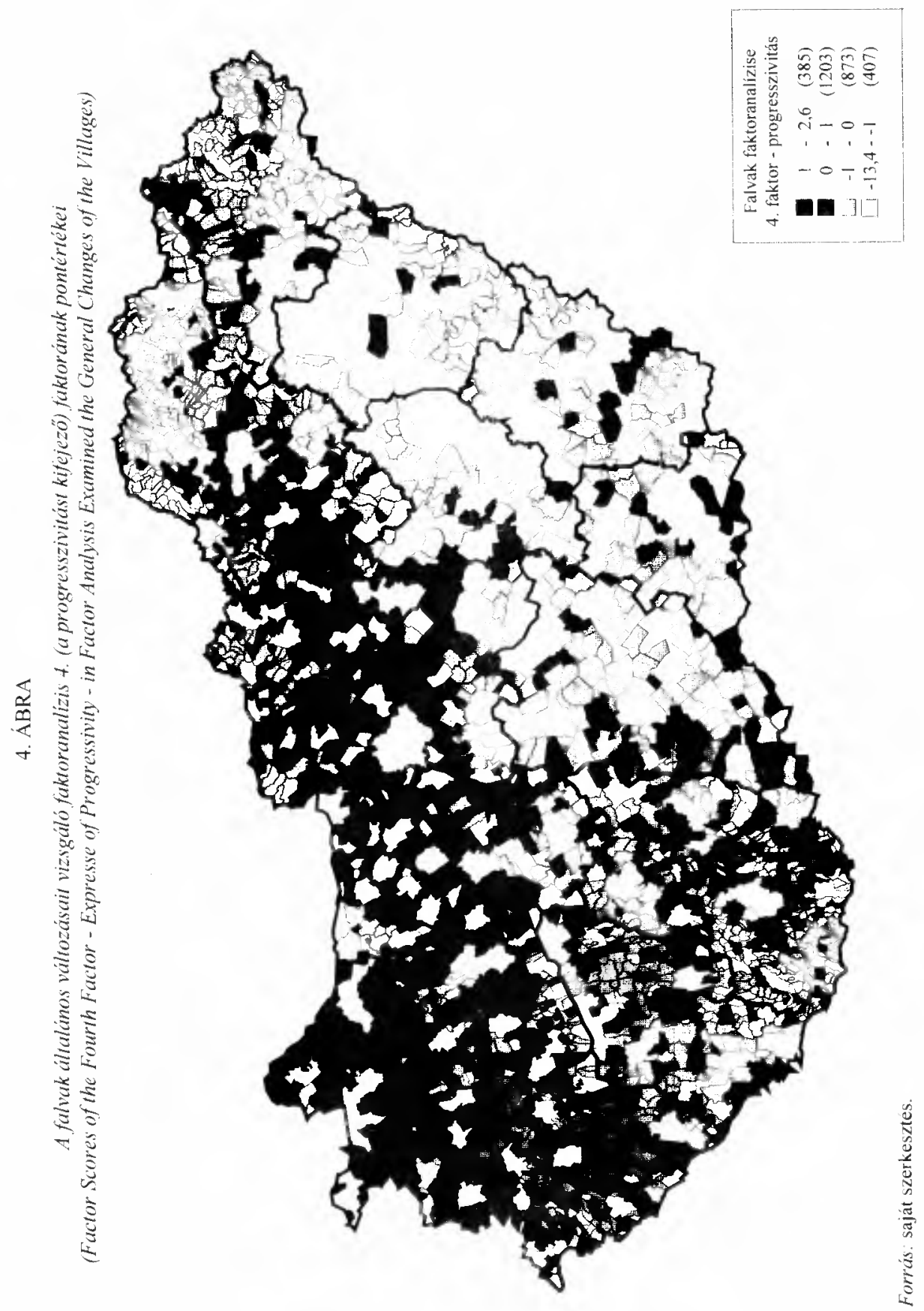


A városokra, némileg bővített mutatórendszeren, eivégzett analízis szerint egészen más kép rajzolódik ki. Egyrészt sokkal erősebb a föfaktor magyarázó ereje $(61,4 \%)$, másrészt az egyébként mégiscsak homogénebbnek tekinthetö városhálózaton belül sokkal erősebb a differenciálódás, mint a teljes állományban. A fö progresszív tényezők: a vállalkozások száma, a magas születési arány, a kedvezó lakásépítési ütem, a magas iskolai végzettség, de a városok mérete is fontos elem. $\mathrm{E}$ tekintetben az Alföld városai nem, vagy alig maradnak el más régiók központjaitól, sőt éppen a régió sajátos városhálózata lehet az új regionális fejlesztés egyik kulcsa. Annál is inkább, mert e településcsoportnál igen fontosak és sokkal erősebben differenciálnak a gazdaság élénkülésére, $s$ a humán eróforrások meglétére és adaptivitására utaló mutatók, melyek - különösen az alföldi városok esetében - maguk után vonják a beruházások élénkủlését. A pozitív főfaktorpontértékủ 21 alföldi városban a kedvezö irányú változások együttes jelentkezése a faktorban ismét az Alfơld „másságának" egyik bizonyitéka (5. táblázat, 5. ábra).

\section{TÁBLÁZAT}

A városok általános faktoranalizisének fỏ faktoraihoz tartozó települések számának és népességének megoszlása országosan és az Alföldön

(Division of the Number and the Population of Settlements Concerned to Principal Factors of General Factor Analysis of Cities in Hungary and in the Great Plain)

\begin{tabular}{|c|c|c|c|c|c|c|c|c|}
\hline \multirow{3}{*}{ Kategória } & \multicolumn{4}{|c|}{ Országos } & \multicolumn{4}{|c|}{ Alföld } \\
\hline & \multicolumn{2}{|c|}{ Telepuilésszám } & \multicolumn{2}{|c|}{$\begin{array}{c}\text { Lakónépesség, } \\
1996\end{array}$} & \multicolumn{2}{|c|}{ Településszám } & \multicolumn{2}{|c|}{$\begin{array}{c}\text { Lakónépesség, } \\
1996\end{array}$} \\
\hline & $\mathrm{db}$ & $\%$ & fö & $\%$ & $\mathrm{db}$ & $\%$ & fö & $\%$ \\
\hline 1 felett & 16 & 8,04 & 1717637 & 38,18 & 6 & 6,38 & 736729 & 36,62 \\
\hline $0-1$ & 30 & 15,08 & 1035155 & 23,01 & 15 & 15,96 & 450291 & 22,38 \\
\hline$-1-0$ & 151 & 75,88 & 1739697 & 38,67 & 73 & 77,66 & 824864 & 41,00 \\
\hline-1 alatt & 2 & 1,01 & 6768 & 0,15 & 0 & 0,00 & 0 & 0,00 \\
\hline Összesen & 199 & 100,00 & 4499257 & 100,00 & 94 & 100,00 & 2011884 & 100,00 \\
\hline
\end{tabular}

Forrás: saját számitás.

Mindezek alapján egyértelmü, hogy az Alföld régió településhálózata alapvetően más megközelítésủ és regionális szemléletü fejlesztést igényelhet. Jellemző például a korábban kialakult városcsoportok újjáéledése. $\mathrm{E}$ városcsoportok kialakulása európai jelenség, $s$ alapvetően azt is jelentheti, hogy a városok egyre „sokfélébbek”, a fejlödésük az ún. komplementaritás irányába mozdul el. A fejlesztés és intézménytelepítés - jó közlekedési és kommunikációs összeköttetések esetén ugyanis hatékonyabb és hatásosabb is, ha nemcsak a már egyébként is túlterhelt nagyvárosokba, hanem azok kiegészítö komplementer központjaiba is szervezetten folyik. Szeged és Hódmezővásárhely, Debrecen és a hajdú városok, Kecskemét Nagykőrös és Cegléd, Szolnok és a jász vagy nagykun városok tökéletesen illeszthetök ehhez az elvhez. 


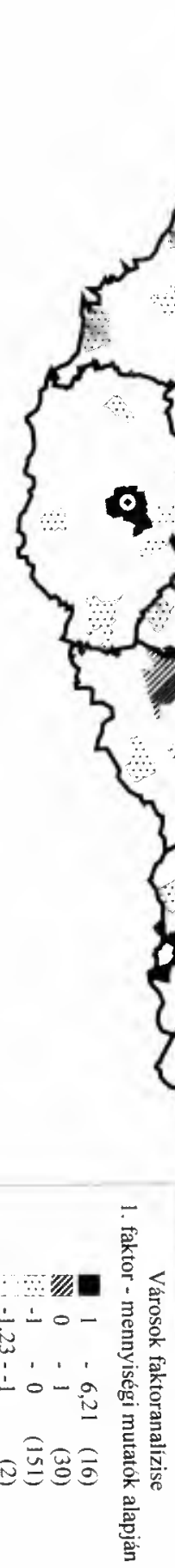

광

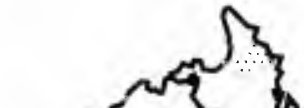

and
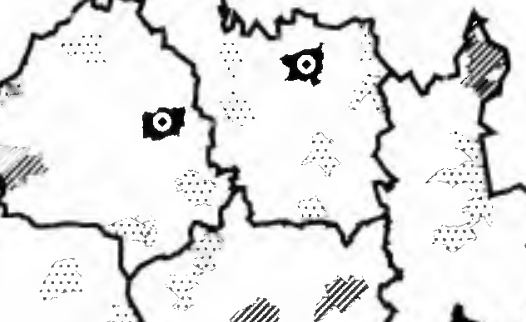

.

魰
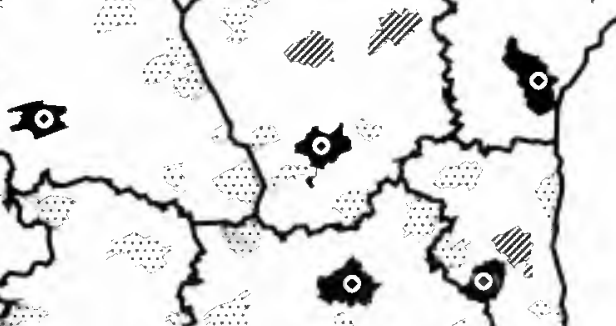

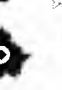
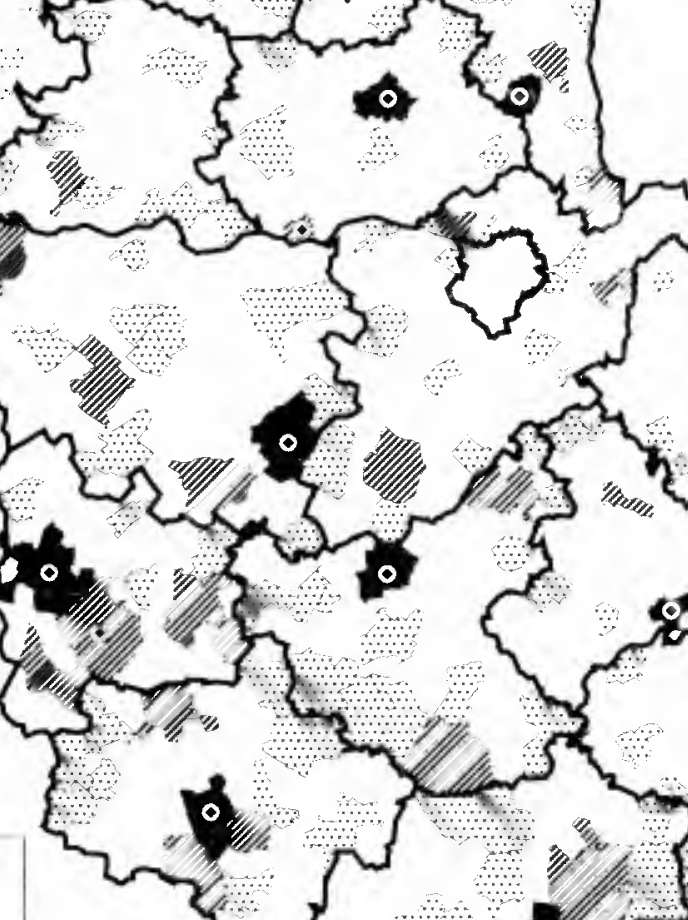
Az új irảnyokat kereső alföldi vidékfejlesztés is csak úgy lehet eredményes, ha a vidékek városi központjainak minősége, kisugárzó hatása erösödik. A tipikus „vidékek" központjainak tekinthető kisvárosok fejlesztése nevesitve is szerepel az Európai Unió új terưletfejlesztési perspektívái között. A kisebb városok fejlesztését különösen a ritkábban lakott és gyenge gazdasági erővel, potenciállal rendelkező térségekben igyekeznek szorgalmazni, ami éppen a szükös erőforrások, a szolgáltatások koncentráltabb felhasználását, illetve elérhetőségét teszi lehetővé.

A kisvárosok és vidékük kapcsolatrendszerében két fö területi típus alakul ki Európában. Azoké, ahol a vidék a város „nyomása alá kerül”, s azoké, ahol a mezőgazdaság egyoldalúsága és hanyatlása jellemző. Érdekes módon az Alföldön is előfordul mind a két fỏ típus. Az előbbinél a város és vidéke konfliktusainak feloldása, a falvak és a városok közös, a környezeti terhelésre is tekintettel levő fejlesztése lesz a jövő fỏ iránya, míg a másik esetben az úgynevezett fenntartható és komplex vidékfejlesztés. Ez utóbbi területeket a diverzifikált fejlesztés irányába igyekeznek terelni a helyi adottságok és sajátosságok maximális kihasználásával. Természetesen tetemes állami, illetve közös pénzforrásból is támogatva, esetleg új gazdasági ágazatok befogadását elősegítve. A fejlesztési programok sora a mobil munkahelyek létesítésétől a megújuló helyi energiaforrások alkalmazásáig vezet. Az Alföld táji-természeti tagoltsága, Bácskától a Tiszahátig alkalmas lehet ilyen típusú programok fogadására és végrehajtására. Ehhez persze az is szükséges, hogy a területfejlesztésnek minden szintjén, így a kistérségek szintjén is kialakuljon az a rugalmas, professzionális tervezö-fejlesztő-inenedzser intézményrendszere, amely képes e programok adaptáciojjára, megszervezésére, végrehajtására.

\section{Az innováció és a tudás térbeli szétteritése}

Természetesen e tanulmány terjedelme nem teszi lehetővé azt, hogy a jövö európai területfejlesztési perspektíváinak minden - az alapdokumentumban pontokba is foglalt - irányát áttekintsük. A telepưléshálózat-fejlesztési föirányhoz is kapcsolva további elágazások, alpontok vannak, amelyek pl. az „Azonos esélyek az infrastruktúra és a tudás elérhetőségében”, illetve „A természeti és kulturális örökség körültekintô menedzselése és fejlesztése" címeket viselik. A társadalmi megújulóképességröl, az innovativitásról, a tudásról szóló pontok általában véve nemcsak a regionális politika eszmeiségét, szellemiségét kívánják szolgálni, hanem azt is rögzítik, hogy az elmaradottabb térségekben fejleszteni kell a felsőoktatást és a kutatást. A humán erőforrások fejlesztése ugyanis a legprogresszivebb megoldás az elmaradottság mérséklésére és felszámolására. Az Alfơld - részben társadalmi tradíciói, illetve városhálózatának még ma is viszonylag fejlett intézményhálózata révén - szintén alkalmas ennek a megoldásnak a követésére. Ha összehasonlítjuk az ország, illetve az Alföld statisztikai-területfejlesztési kistérségeinek általános és kulturális fejlettségét egy sokmutatós rendszer segítségével, akkor világosan érzékelhetó, hogy a vizsgált régiónk sajátos városhálózata révén a kulturális, oktatási, közintéz- 
ményi ellátottság kedvezőbb képet rajzol, mint a gazdaság és az infrastruktúra által meghatározott általános fejlettségi szint.

Hatalmas kihívás tehát az Alföld városai, az Alföld társadalma számára, hogy képes lesz-e az új európai perspektívák elveihez szinte teljes mértékben illeszkedö esélyeit, lehetőségeit kihasználni. Ma még nem dőlt el igazán az a kérdés sem, hogy a humán erőforrások tudatos fejlesztésével a régió gazdasági színvonala is emelkedni, integrálódni, felzárkózni fog-e, vagy a most gyengébb gazdaság színvonalára zuhan vissza a kultúra és oktatás színvonala is. Ha tovább veszít arányaiból és jelentőségéből az Alföld felsőoktatási és kutatási kapacitása, ha bezárnak a vidéki, kisvárosi gimnáziumok, ha nem indul meg a modern tudást, idegen nyelvismeretet is adó, konvertálható szakképzés, akkor az utóbbi variáns bekövetkezése valószínüsíthető. Ha a mostani - és sajnos nemcsak látszólagos - válságjelenségek ellenére az informatika, az innováció, a tudásalapú ipar, és a $\mathrm{K}+\mathrm{F}$ együttesen is hatékonyságra törekvö, valóban új ágazatként jelenik meg az Alföld tudatos fejlesztésében, akkor valószínüsíthető a sikeres regionális integráció. Ennek egyik kulcsa a közlekedési és kommunikációs kapcsolatok elsődleges fejlesztése (6. táblázat, 6. ábra).

\section{TÁBLÁZAT}

Az általános faktoranalizis 3. faktorához tartozó települések számának és népességének megoszlása országosan és az Alföldön

(Distribution of the Number and the Population of Settlements Concerned to the

3. Factor of General Factor Analysis in Hungary and in the Great Plain)

\begin{tabular}{|c|c|c|c|c|c|c|c|c|}
\hline \multirow{3}{*}{ Kategória } & \multicolumn{4}{|c|}{ Országos } & \multicolumn{4}{|c|}{ Alföld } \\
\hline & \multicolumn{2}{|c|}{ Településszám } & \multicolumn{2}{|c|}{ Lakónépesség, 1996} & \multicolumn{2}{|c|}{ Településszám } & \multicolumn{2}{|c|}{ Lakónépesség, 1996} \\
\hline & $\mathrm{db}$ & $\%$ & fö & $\%$ & $\mathrm{db}$ & $\%$ & fö́ & $\%$ \\
\hline $0,5-1,5$ & 385 & 65,37 & 1201964 & 32,11 & 81 & 81,82 & 418917 & 34,04 \\
\hline $1,5-2,8$ & 157 & 26,66 & 2377593 & 63,53 & 16 & 16,16 & 810256 & 65,84 \\
\hline 2,8 felett & 47 & 7,98 & 163144 & 4,36 & 2 & 2,02 & 1456 & 0,12 \\
\hline Összesen & 589 & 100,00 & 3742701 & 100,00 & 99 & 100,00 & 1230629 & 100,00 \\
\hline
\end{tabular}

Forrás: saját számitás.

\section{Zárógondolatok}

Az bizonyos, hogy az Alföld jövője, sorsa - mint ezt az új, még nem véglegesített európai regionális területfejlesztési perspektívákkal való vázlatos összevetése is igazolta - az összeurópai területi, regionális fejlődésben is egyre jellemzöbbé váló szellemiségen, innovativitáson, kreativitáson, társadalmi-partneri együttmüködési készségeken, illetve azok fejlesztésén fog elsösorban múlni, és csak másodsorban a pénzügyi források nagyságán. Pontosítva: az európai regionális fejlesztési rendszerben ezek a bizonyos források csak e „készségek”, szakszerủ koncepciók, programok, tervek, jól müködö intézményhálózat megléte, a humán eröforrások adaptivitásának, a helyi társadalom megszerveződésének „bizonyítása” esetén érhetők el, hívhatók le. 
8
3
3
0
0
8
8
8
3
3
3
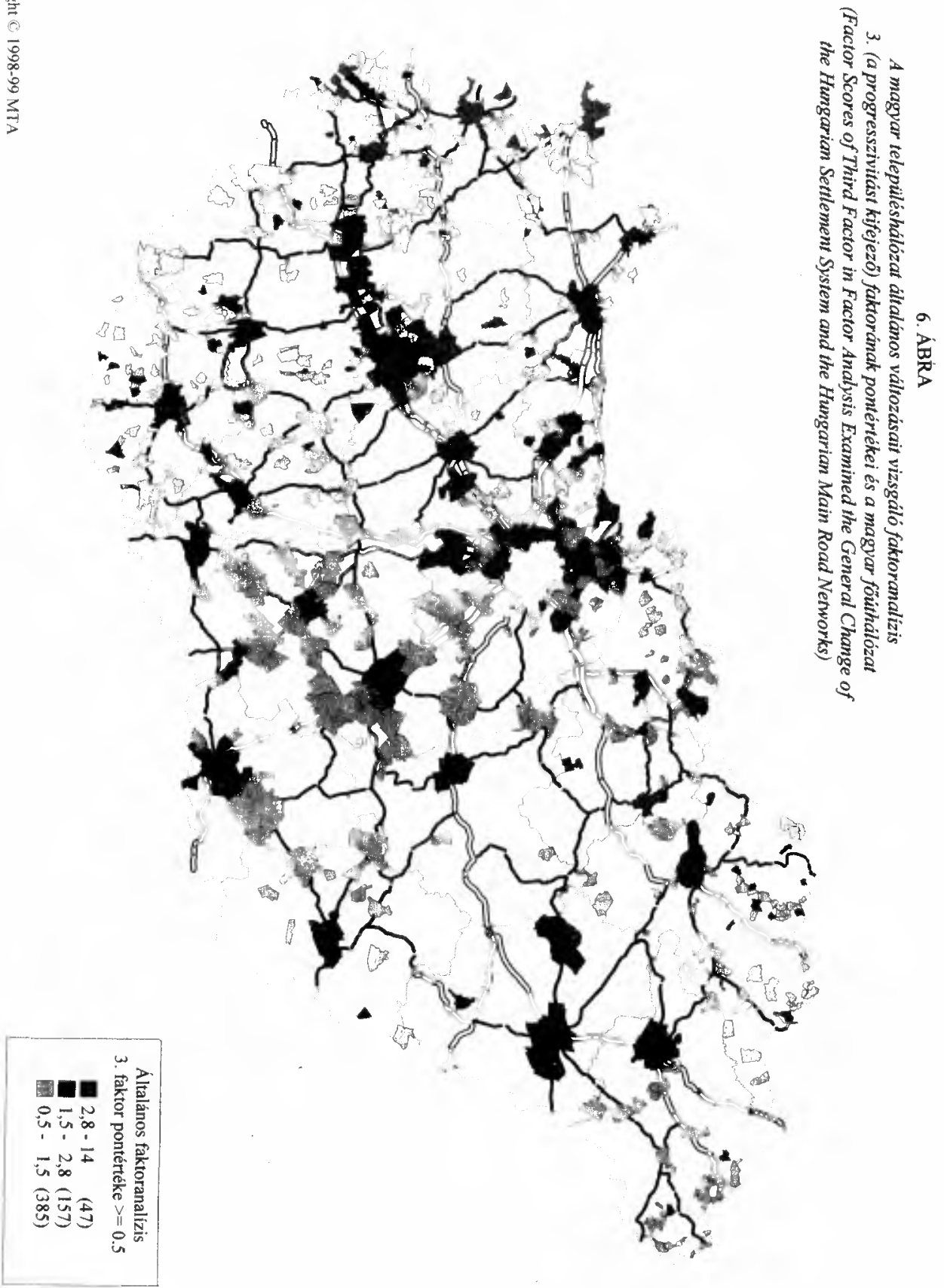
Az Alföld régiónak a bevezetöben taglalt és faktoranalízisekkel bizonyított „,mássága", homogenitása, relatíve fejlett és jó eloszlású városhálózata, történelmi tapasztalatai és karakteres regionális jellegzetességeinek az új európai területfejlesztési perspektíváknak való megfelelése reményt adhat a megújulásra, az elkerülhetetlen modernizációra és a különleges földrajzi pozíciója alapján nemzetközi jelentöségủ integrációra is.

\section{Jegyzetek}

${ }^{1}$ A tanulmány az MTA Stratégiai Kutatások Alfôld II. Kutatási Programjához készült elötanulmányok felhasználásával készullt.

${ }^{2}$ Kemény Zsigmond aforizmája.

${ }^{3}$ A mutatók adatai, a térképek és a táblázatok tekintettel a mért és kőzigazgatásilag bekovetkezett 199096 közötti változásokra, az 1990-es bázisév telepủlési és térképi állományára vonatkoznak.

\section{Irodalom}

Beluszky P.-Csatári B. (1998) Kísérleti faktoranalizis-számitások az ország és az Alföld településállománya differenciálódásának meghatározásához. Alfold II. Kutatási Program, kézirat. Kecskemét, MTA RKK ATI.

Csatári B. (1995) Az Alföld helyzete és perspektivái. Nagyalfơld Alapitvány kơtetei 4. Békéscsaba, Nagyalfơld Alapítvány.

Enyedi Gy. (1996) Regionális folyamatok Magyarországon. Budapest, Hilscher Rezső Szociálpolitikai Egyesulet.

Erdösi F. (1998) A transzeurópai hálózatok hatása a teruleti fejlödésre. - Tér és Társadalom. 3. 27-50. o

Európai Teruletfejlesztési Perspektíva. (1998a) - Falu-Vảros-Régió 1. 33-35. o.

Európai Területfejlesztési Perspektíva. (1998b) - Falu-Város-Régió 2. 25-41. o.

Horváth Gy. (1998) Az európai regionális fejlödés és politika tálatai. - Tér és Társadalom. 3. 1-26. o.

Rechnitzer J. (1993) Szétszakadás vagy felzárkózás. Győr, MTA RKK.

\section{THE GREAT HUNGARIAN PLAIN AND THE NEW PERSPECTIVES OF REGIONAL DEVELOPMENT IN EUROPE}

\section{BÁLINT CSATÁRI}

The Great Hungarian Plain is one of the most contradictory large regions in Hungary. The particular features of its historical development, the environmental hazards, the transitory crisis of the agri-business and the economy in the region, the extremely underdeveloped, peripheral situation of several micro-regions - on the other hand, the rapid catching up and development of a few towns in the region and the gradual appreciation of its transport corridors, considering that the Great Plain will be the Eastern border region of the European Union after the enlargement: all these factors underline the importance of the "difference", the uniqueness of the Great Hungarian Plain. 
The Great Plain is homogeneous from the aspect of quite a large number of regional factors, and its natural borders reach beyond the country borders. The development of the region involves many elements which require a brand new view and approach from both the regional policy of Hungary and the countries adjacent to the Great Plain.

The study is actually a train of thoughts, partly established by regional and municipal surveys, which compares the future possibilities of the Great Hungarian Plain to the new, European level spatial approaches stated in the document called "European Spatial Development Perspectives", accepted in 1997. The main finding of the paper is that the endowments and possibilities of the Great Hungarian Plain, lying in its individual regional, environmental, economic, transport and social situation and its settlement network, are better suited to these new, more subtle European structural and cohesion principles than the former, often mechanical, equalisation systems.

New and successful regional development solutions are offered for the Great Plain by the integration to the Trans-European Networks (TEN-s), a complementary urban development, the promotion of the relationship between the towns and their rural hinterlands, the dissemination of innovation and knowledge, and the preservation and creative management of the environmental and cultural heritage.

The spatial development of the Great Hungarian Plain, with a view to the shaping Carpathians and the Danube-Tisza-Körös-Maros Euro-regions, has definite "European dimensions", as well. 